Research Article

\title{
Green Synthesis of Silver Nanoparticles Using Stem of Ruta graveolens L: Antibacterial, Cytotoxic and Antioxidant Activity
}

\section{*Remya Varadarajan, Bhakti Hirani, Chandravilas Kesavan Prashant, Krutika Devidas Patil, Rakhi Amarchandra Jana,} Shamal Hrushikesh Chavan

Department of Biotechnology, Pillai College of Arts, Commerce \& Science, Dr. K.M Vasudevan Pillai Campus, Plot No.10, Sector 16, New Panvel, Maharashtra, India.

*Corresponding author's E-mail: remyavaradarajan18@gmail.com

Received: 03-10-2021; Revised: 18-12-2021; Accepted: 26-12-2021; Published on: 15-01-2022.

\section{ABSTRACT}

The green chemistry approach using plants involves phytoconstituent mediated reduction process for synthesis of nanoparticles. Biogenic Silver nanoparticles (AgNPs) were synthesized using aqueous stem extract of Ruta graveolens. The adopted biological method is compatible with green chemistry principles because the plant extract acts as a dual functional molecule: as reductant and a stabilizing agent for the synthesis of AgNPs. The UV-visible spectra confirmed that reduction of silver ions for Ruta stem extract at $485 \mathrm{~nm}$ on 24-hour incubation. FT-IR spectroscopic spectrum showed the peaks at 3507, 2829, 1579, 1010, 755 which are characteristic of flavonoids and terpenoids present in the stem. The zeta potential of Ruta AgNPs was found to be $-35.4 \mathrm{mV}$ which indicate that the nanoparticles are quite stable due to charge accumulation on its surface. The TEM micrograph reveals that the particles were of spherical shape \& monodispersed, the average size of the particles is around $15 \mathrm{~nm}$. Ruta AgNPs showed cytotoxicity against cancer cells and the results indicated that with the increase in Ruta AgNPs concentration there was a significant $(p<0.05)$ decrease in cell viability of HepG2 as compared to control. The antioxidant activity of Ruta AgNP was confirmed by ABTS radical scavenging activity. Ruta AgNPs may provide novel resources for the evaluation and development of newer, safer, and effective antimicrobial and antiproliferative drug formulations.

Keywords: Ruta graveolens, silver nanoparticles, characterization, Cytotoxicity, antimicrobial, antioxidant.

QUICK RESPONSE CODE $\rightarrow$

DOI:

10.47583/ijpsrr.2022.v72i01.002

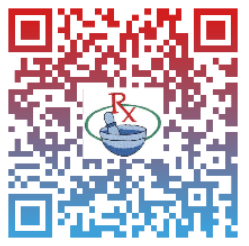

DOI link: http://dx.doi.org/10.47583/ijpsrr.2022.v72i01.002

\section{INTRODUCTION}

N

anoparticles, are particles with a size ranging from 1 to $100 \mathrm{~nm}$ in two or three dimensions according to the American Society for Testing and Materials (ASTM) standard definition. Noble metal nanoparticles have also received much interest in recent years because they have immense applications in medicine, biology, material science, physics, and chemistry. Silver nanoparticles (AgNPs) have garnered considerable attention because of their special properties, which include good electrical conductivity, chemical stability, and catalytic and antibacterial properties ${ }^{1}$. AgNPs have been used widely in the health industry, food storage, in cloth coatings, and also in a range of environmental applications as antimicrobial agents. AgNPs are being produced in a multitude of ways, including physical and chemical processes. To obtain AgNPs, green chemistry has emerged as a clear and viable alternative to more complex chemical synthesis. Green synthesis of metallic nanoparticles using plant extract is based on ability of plant metabolites to reduce metal ions and stabilize them. The following properties can be considered as advantages of using plants for nanoparticle synthesis; availability, safety in handling, and presence of a variety of phytoconstituents. Plant crude extracts contain novel secondary metabolites including phenolic acid, flavonoids, alkaloids, and terpenoids, which are mainly responsible for the reduction of ionic metal into bulkmetallic nanoparticles ${ }^{2}$.

Ruta graveolens $L$. is a small shrub or evergreen herb with a strong odour. It belongs to the Rutaceae family. Ruta graveolens L. (Rutaceae) is traditionally used in Indian herbal medicine to treat rheumatism, arthritis, and other inflammatory conditions ${ }^{3}$. The roots and aerial parts of the plant contain over 120 natural compounds. Acridone alkaloids, coumarins, volatile substances, terpenoids, flavonoids, and furoquinolines are some of the most common phytochemical compounds contained in R.graveolens ${ }^{4}$. Hence it is expected that silver nanoparticles synthesized using stem extract may be useful in medicine. The main mechanism considered for the nanoparticle synthesis process is reduction due to phytochemicals. Green synthesis provides advancement over chemical and physical method as it is cost effective, environment friendly, easily scaled up for large scale synthesis and in this method, there is no need to use high pressure, energy, temperature and toxic chemicals. AgNPs are one of the most promising antimicrobial materials applied in nanomedicine. AgNPs can interact with the microorganism cell wall, generating reactive oxygen species that ultimately leads to cell death ${ }^{5}$. 
This is the first study to use Ruta graveolens stem aqueous extract in the synthesis of AgNPs. It is important to analyse the prepared nanoparticles before application in order to resolve the safety problem and use the full potential of any nano material in the purpose of human welfare, nanomedicines, or the health care industry. Techniques such as, UV-visible spectroscopy, TEM (Transmission Electron Microscopy), FTIR (Fourier Transform Infra-Red spectroscopy), and DLS (Dynamic Light Spectroscopy) were used to characterize the synthesized silver nanoparticles. The synthesized Ruta graveolens mediated silver nanoparticle were evaluated for antibacterial property, the cytotoxic effect and antioxidant activity.

\section{METHODS}

\section{Chemicals, Reagents and Media}

The plant material, Ruta graveolens were collected from Kerala, India and identified taxonomically. Silver nitrate $\left(\mathrm{AgNO}_{3}\right)$, Mueller Hinton agar and Mueller Hinton broth and 3-(4, 5-dimethylthiazol-2-yl)-2,5-diphenyltetrazolium bromide (MTT), Dulbecco's Modified Eagle's Medium supplemented with $10 \%$ fetal bovine serum (FBS), nutrient media were purchased from Himedia Laboratories Pvt. Ltd., Mumbai, India and used without any further purification. Cell lines (HepG2) were obtained from National centre for cells Sciences (NCCS), Pune, India.

Collection of plant samples and preparation of $R$. graveolens extract

The stem extract was prepared from the freshly collected plant, Ruta graveolens. They were surface cleaned thoroughly with running tap water, followed by sterile distilled water. $5 \mathrm{~g}$ stem were cut into small pieces and boiled with $100 \mathrm{ml}$ deionized water for $5 \mathrm{~min}$. The prepared plant extract was filtered through Whatman No. 1 filter paper and the aqueous filtrate was used further to synthesize AgNPs.

\section{Biosynthesis of AgNP}

Biological reduction of $\mathrm{AgNO}_{3}$ was carried out as follows. A stock solution of $10 \mathrm{mM} \mathrm{AgNO}_{3}$ was used for the preparation of varying $\mathrm{AgNO}_{3}$ concentration (0.1 - 1.0 $\mathrm{mM}$ ). For all the preparations, $5 \mathrm{ml}$ plant extract was used. The prepared flasks were kept in dark for 24 hours at room temperature for biosynthesis of silver nanoparticles to take place.

\section{Characterization by UV-Visible spectrophotometry}

The formation of AgNPs was primarily observed by monitoring the change in colour of the extract after treatment with $\mathrm{AgNO}_{3}$ (0.1 to $1 \mathrm{mM}$ ). The bio-reduction of silver $\left(\mathrm{Ag}^{+} \rightarrow \mathrm{Ag}^{0}\right)$ ions in stem aqueous extract was monitored with the UV-visible double beam spectrophotometer (Model no: UV 1800, Shimadzu, Japan) in the wavelength range from 300 to $700 \mathrm{~nm}$. Distilled water was used as the blank.

\section{Transmission electron microscopy (TEM)}

The particle size and microstructure were studied by transmission electron microscopy PHILIPS CM 200 operating at $200 \mathrm{kv}$. Synthesized silver nanoparticles were sonicated for 30 minutes to 1 hour in $100 \%$ ethanol to obtain a homogenous suspension of nanoparticles. A drop of the AgNP suspension was placed on to carbon-coated copper grid, dried under IR light and loaded in to the TEM microscope to obtain image.

\section{Zeta Potential}

Zeta Potential is used as an indicator of stability of nanoparticles. The analysis of the biologically synthesized silver nanoparticles from $R$. graveolens stem extract was performed using Horiba Scientific Nanopartica Nanoparticle Analyser SZ-100 (Japan). About $100 \mu \mathrm{l}$ of sample was diluted with $1 \mathrm{ml}$ of sterile deionzed water and loaded in to the folded capillary cells. The measurements were made at $30.5^{\circ} \mathrm{C}$ with the electrode voltage of $3.3 \mathrm{~V}$.

\section{Dynamic light scattering (DLS)}

The DLS method is a special method of measuring particle size in the range of $1-5000 \mathrm{~nm}$, where a laser beam is made to incident on the nanoparticle suspended in the liquid (NPs are under brownian motion). The scattered beam intensity (fluctuation) with time (microsecond) was measured. The analysis of the biologically synthesized silver nanoparticles was performed using Horiba Scientific Nanopartica Nanoparticle Analyser SZ-100 (Japan).

\section{FT-IR spectroscopy}

Synthesized nanoparticles were subjected to FTIR spectroscopy, Bruker 3000 Hyperion Microscope with vertex $80 \mathrm{FTIR}$ in the range of $400-4000 \mathrm{~cm}^{-1}$ at Spectral resolution of $0.2 \mathrm{~cm}^{-1}$. The AgNPs were grinded with $\mathrm{KBr}$ and pressed to form pellets of around 0.5 to $1.0 \mathrm{~mm}$ thickness. The pellets were later placed in the IR path and the spectrum was analysed.

\section{Antimicrobial analysis}

The AgNPs were separated by centrifugation at 10,000 rpm for 15 minutes, the pellet thus obtained was redispersed in sterile distilled water. The synthesized AgNPs of Ruta graveolens was tested for antibacterial activity by minimum inhibitory concentration (MIC) and minimum bactericidal concentration (MBC) against Gram-positive bacteria Staphylococcus aureus and Gram-negative bacteria Escherichia Coli and Klebsiella pneumoniae and fungus Candida albicans.

\section{Minimum Inhibitory Concentration (MIC)}

The MIC and MBC of green synthesized AgNPs were done using the method described in the guideline of CLSI (2012). The MIC of the biologically synthesizes silver nanoparticles was determined using sterile Mueller Hinton broth dilution method with silver nanoparticle concentration ranging from $0.5 \mu \mathrm{g} / \mathrm{ml}$ to $500 \mu \mathrm{g} / \mathrm{ml}$. 18 hours old bacterial culture was resuspended in sterile saline such that the 
culture density reached that of McFarland`s standard having approximate cell density of $1.5 \times 10^{8} \mathrm{CFU} / \mathrm{ml}$. The prepared bacterial culture was inoculated in the standard tubes of silver nanoparticles. A positive control was maintained by inoculating the culture in the sterile $\mathrm{MH}$ broth; whereas for negative control, the sterile $\mathrm{MH}$ broth was kept uninoculated. All the tubes were then incubated at $37^{\circ} \mathrm{C}$ for 24 hours. The MIC was noted by observing the tubes for turbidity. The lowest concentration of antimicrobial agent that inhibits the visual growth of the organism is noted as MIC.

\section{Minimum Bactericidal Concentration (MBC)}

Minimum Bactericidal Concentration (MBC) is the lowest concentration $(\mu \mathrm{g} / \mathrm{ml})$ of the nanoparticles that kill the particular bacteria. It was determined by the spot inoculating the AgNP concentrations on the Sterile $\mathrm{MH}$ agar plates that did not show visible growth in minimum inhibitory concentration tubes. Suitable positive and negative controls were maintained. The plates that did not show visible growth after incubation at $37^{\circ} \mathrm{C}$ for 24 hours were noted as the minimum bactericidal concentration.

Table 1: Preparation of standard dilutions of silver nanoparticles

\begin{tabular}{|c|c|c|c|c|c|}
\hline Tube no & $\begin{array}{l}\text { Concentration } \\
(\mu \mathrm{g} / \mathrm{ml})\end{array}$ & $\begin{array}{c}\text { Volume of AgNP } \\
(\mu \mathrm{l})\end{array}$ & $\begin{array}{l}\text { Volume of Nutrient broth } \\
(\mu \mathrm{l})\end{array}$ & $\begin{array}{l}\text { Volume of Culture } \\
\qquad(\mathrm{ml})\end{array}$ & $\begin{array}{l}\text { Total Volume } \\
\text { (ml) }\end{array}$ \\
\hline 1 & 0.5 & 2.5 & 4997.5 & 0.1 & 5 \\
\hline 2 & 2.5 & 12.5 & 4987.5 & 0.1 & 5 \\
\hline 3 & 5.0 & 25 & 4975.0 & 0.1 & 5 \\
\hline 4 & 10.0 & 50 & 4950.0 & 0.1 & 5 \\
\hline 5 & 25.0 & 125 & 4875.0 & 0.1 & 5 \\
\hline 6 & 50.0 & 250 & 4750.0 & 0.1 & 5 \\
\hline 7 & 75.0 & 370 & 4625.0 & 0.1 & 5 \\
\hline 8 & 100.0 & 500 & 4500.0 & 0.1 & 5 \\
\hline 9 & 200.0 & 1000 & 4000.0 & 0.1 & 5 \\
\hline 10 & 500.0 & 2500 & 2500.0 & 0.1 & 5 \\
\hline Positive Control & - & - & 5000.0 & 0.1 & 5 \\
\hline $\begin{array}{l}\text { Negative } \\
\text { Control }\end{array}$ & - & - & 5000.0 & - & - \\
\hline
\end{tabular}

\section{Cytotoxicity assay}

Cells were maintained in DMEM media supplemented with $10 \%$ FBS. Confleuent cells were passaged every third day and allowed to grow in T-flask kept in $\mathrm{CO}_{2}$ incubator at $37^{\circ} \mathrm{C}$. The MTT Assay ${ }^{6}$ is a sensitive, quantitative and reliable colorimetric assay that measures viability, proliferation and activation of cells. The assay is based on the capacity of mitochondrial dehydrogenase enzymes in living cells to convert the yellow water-soluble substrate 3 (4,5- dimethylthiazol-2-y1)-2,5-diphenyl tetrazolium bromide (MTT) into a dark blue formazan product that is insoluble in water. Viable cells are able to reduce the yellow MTT under tetrazolium ring cleavage to a waterinsoluble purple-blue formation which precipitates in the cellular cytosol and can be dissolved after cell lysis, whereas cells being dead following a toxic damage, cannot transform MTT. Cells were seeded at $37^{\circ} \mathrm{C}$ for $24 \mathrm{~h}$ prior to treatment with AgNPs. Cells were treated with different concentration of AgNPs (200 and $400 \mu \mathrm{g} / \mathrm{ml}$ ) and DMSO controls were also maintained. The viable cell percentage was calculated, taking into account the $100 \%$ viability of untreated cells.

$\%$ viability $=[($ Absorbance of treated cell - Absorbance of blank)/ (Absorbance of vehicle control - Absorbance of blank) $\times 100]$.

\section{ABTS Free Radical Scavenging Assay}

The ABTS radical scavenging activity of different concentrations of Ruta mediated silver nanoparticles was estimated by a standard protocol ${ }^{7}$. 2mM ABTS was dissolved in $50 \mathrm{ml}$ of distilled water. $70 \mathrm{mM}$ Potassium per sulphate was prepared by dissolving $0.0378 \mathrm{gm}$ in $2 \mathrm{ml}$ of distilled water. Stock solution was prepared by mixing $200 \mu \mathrm{l}$ of potassium per sulphate in $50 \mathrm{ml}$ of ABTS and stored in dark for 12 hours. Prior to use the solution was diluted with ethanol to get an absorbance of 0.7 at $734 \mathrm{~nm}$. Free radical scavenging activity was assessed by mixing $20 \mu \mathrm{l}(50,100$ and $200 \mu \mathrm{g} / \mathrm{mL})$ of Ruta AgNPs with $4 \mathrm{ml}$ of ABTS working standard. The mixture was left for $30 \mathrm{~min}$ at room temperature and the absorbance was measured using a spectrophotometer at $734 \mathrm{~nm}$. Ascorbic acid was taken as a standard. ABTS free radical scavenging percentage activity was calculated using the following formula:

\section{ABTS radical scavenging (\%)}

$=[$ Absorbance of control - Absorbance of sample)/Absorbance of control] $\times 100$ 


\section{Statistical analysis}

Statistical analyses were performed using one way analysis of variance (ANOVA) followed by Dunnett's test using SPSS software package (version 18.0) and $p$ values less than 0.05 were considered significant. The results are denoted as mean \pm standard deviation of six experiments.

\section{RESULTS}

\section{Biologically synthesized silver nanoparticles}

In biological synthesis of AgNPs (Fig.1) after addition of Ruta stem extract to the solution of silver nitrate, the solution changed from colourless to dark orangish-brown. The appearance of color in reaction flasks was the indication of AgNPs formation due to bio-reduction process. The colour intensity increased as a function of time due to the reduction of $\mathrm{Ag}+$.

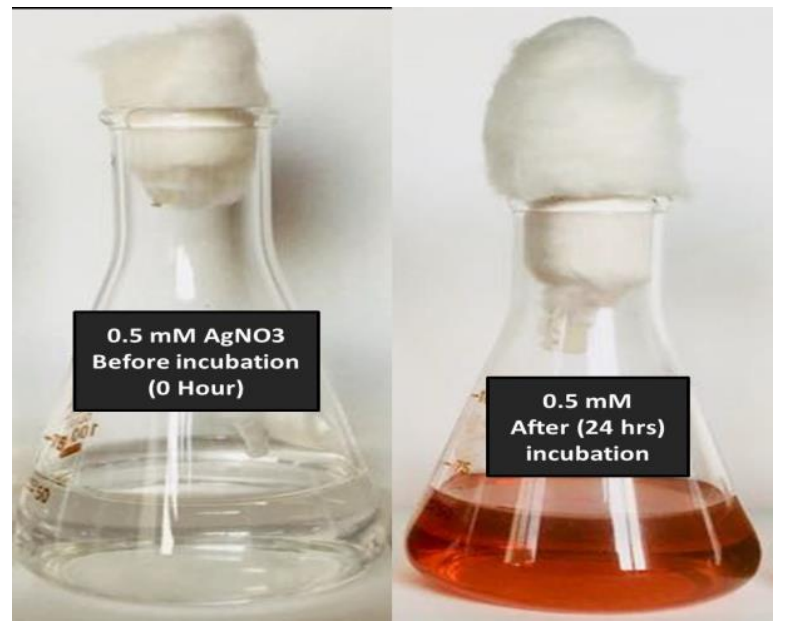

Figure 1: Synthesis of silver nanoparticles using ruta shoot extract (left - 0 hours) and (right - after 24 hours of incubation)

\section{UV-Visible spectrophotometry:}

The absorption spectra of Ruta AgNP (Fig.2) showed the characteristic surface-plasmon of silver nanoparticles. The UV-visible spectra confirmed that reduction of silver ions at $485 \mathrm{~nm}$ on 24 hour incubation.

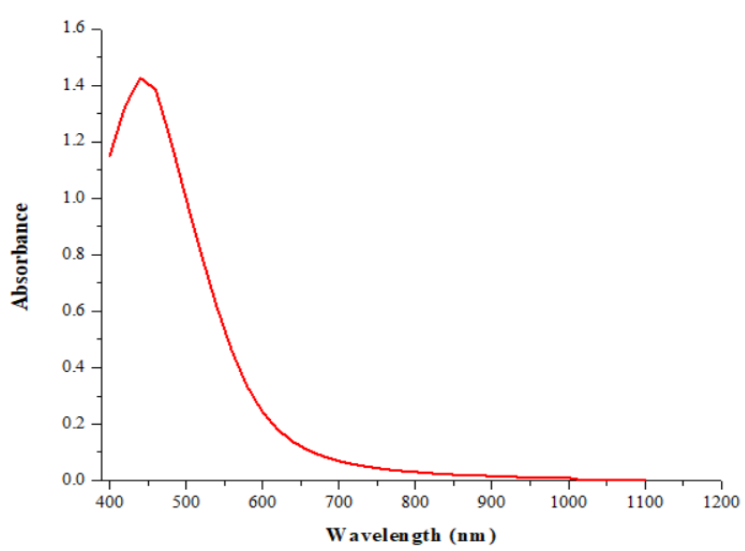

Figure 2: UV-visible spectrum of Silver nanoparticles synthesized using $0.5 \mathrm{mM}$ AgNO3 solution

\section{Transmission electron microscopy}

The shape and size of the AgNPs were elucidated with the help of TEM (Fig.3). The particles were of spherical shape \& monodispersed. The TEM micrograph \& the particle size distribution suggest that the size of the particles were around $15 \mathrm{~nm}$.

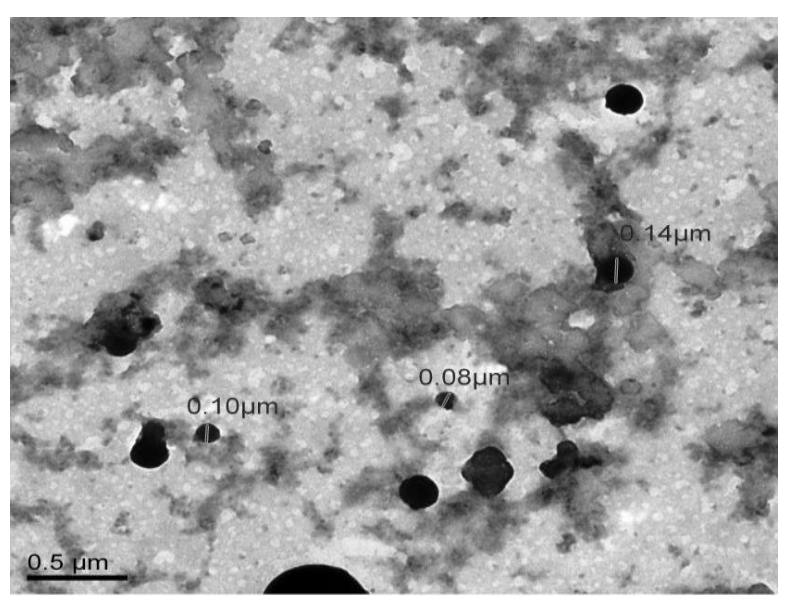

Figure 3: TEM micrographs of Ruta stem AgNPs

\section{Zeta Potential}

The nanoparticles are most stable if the zeta potential values are higher than $+30 \mathrm{mV}$ or lower than $-30 \mathrm{mV}$. The zeta potential of silver nanoparticles synthesized from ruta stem (Fig.4) was found to be-35.4 mV (which indicates that the nanoparticles are quite stable due to charge accumulation on its surface. This columbic repulsion helps in keeping the nanoparticles dispersed, prevents agglomeration and thus remains stable for months together.

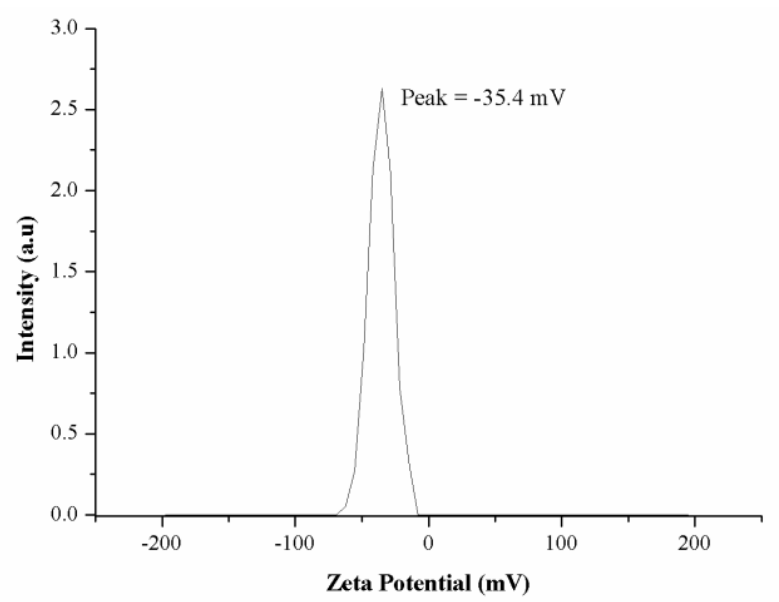

Figure 4: Zeta Potential of Ruta stem AgNPs

\section{Dynamic light scattering (DLS)}

The particle size as obtained by DLS for ruta stem AgNPs (Fig. 5) was found to be $130 \mathrm{~nm}$. The values from DLS are much higher than those from TEM. The DLS intensity shows values around 5-7 times higher than the results obtained from TEM. These results may be due to broad distribution formed by mixing two particles. 


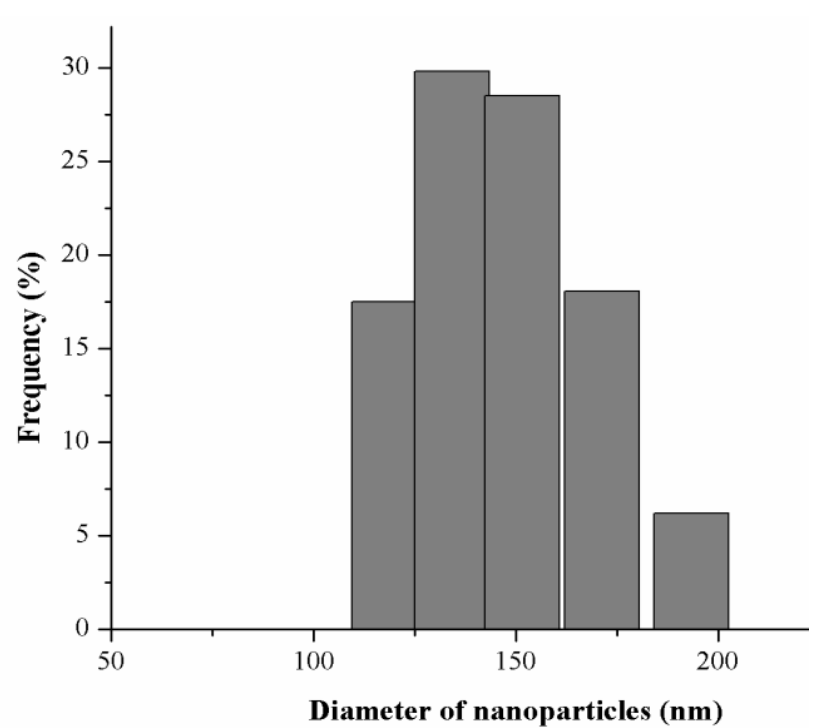

Figure 5: DLS of Ruta stem AgNPs

\section{Fourier transform-Infrared (FT-IR) spectroscopic analysis}

To characterize and identify the biomolecules that were bound specifically on the synthesized Ag NPs, FT-IR spectroscopic analysis was utilized. The spectrum so obtained, as shown in Fig. 6 shows the peaks at 3507, 2829, 1579, 1020, 755 are characteristic of flavonoids and terpenoids present in the stem. These bands corresponding to the stretching vibration of methylene, antisymmetric stretching, vibration of methylene, $\mathrm{C}-\mathrm{H}$ stretching, $\mathrm{C}-\mathrm{C}$ stretching vibration of aromatic, $\mathrm{C}=\mathrm{O}$ stretching, $\mathrm{C}-\mathrm{H}$ stretching vibration and $\mathrm{C}-\mathrm{N}$ stretching of amines. The band position between 500 and 700 are due to $\mathrm{C}-\mathrm{C}$ and $\mathrm{C}-\mathrm{H}$ phenyl ring substitution as expected for this plant. FTIR results suggest that Ruta graveolens acts as a good bioreductant for biosynthesis of silver nanoparticles.

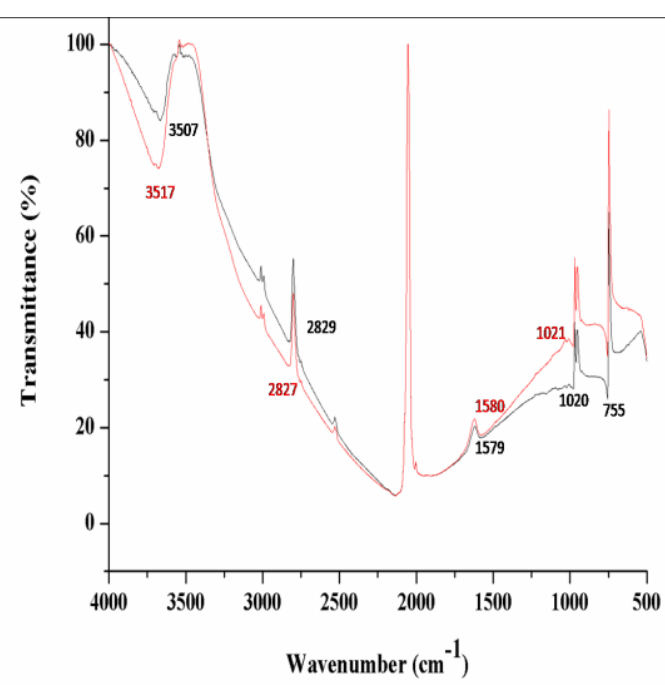

Figure 6: FTIR of Ruta stem AgNPs

\section{Minimum inhibitory concentration (MIC) and Minimum bactericidal concentration (MBC)}

Different concentrations of Ruta AgNPs were tested (Table. 2) against E. Coli, S. aureus, C. albicans and $K$. pneumonia. For $E$. coli, after incubation at $37^{\circ} \mathrm{C}$ for 24 hours, turbidity was observed from concentration $0.5-10$ $\mu \mathrm{g} / \mathrm{ml}$ tubes of silver nanoparticles, since no growth was observed from concentration $25 \mu \mathrm{g}$ onwards, the MIC was found to be $25 \mu \mathrm{g} / \mathrm{ml}$. The suspension from tubes 25 $500 \mu \mathrm{g} / \mathrm{ml}$ was inoculated on to sterile $\mathrm{MH}$ agar plates of the same concentrations and incubated at $37^{\circ} \mathrm{C}$ for 24 hours, no growth was observed from $50-500 \mu \mathrm{g} / \mathrm{ml}$ and hence the $\mathrm{MBC}$ was found to be $50 \mu \mathrm{g} / \mathrm{ml}$. Similarly, the $\mathrm{MIC}$ and MBC for S. aureus was found to be $10 \mu \mathrm{g} / \mathrm{ml}$ and $25 \mu \mathrm{g} / \mathrm{ml}$, for $K$. pneumonia it was found to be $25 \mu \mathrm{g} / \mathrm{ml}$ and $50 \mu \mathrm{g} / \mathrm{ml}$ and for C. albicans it was found to be 25 $\mu \mathrm{g} / \mathrm{ml}$ and $50 \mu \mathrm{g} / \mathrm{ml}$ respectively.

Table 2: Minimum inhibitory concentration (MIC) and Minimum bactericidal concentration (MBC) of Ruta stem AgNP on selected microorganisms

\begin{tabular}{|c|c|c|c|c|c|c|c|c|}
\hline \multirow{2}{*}{ Tube } & \multicolumn{2}{|c|}{ E. coli } & \multicolumn{2}{|c|}{ S. aureus } & \multicolumn{2}{|c|}{ C. albicans } & \multicolumn{2}{|c|}{ K. pneumonia } \\
\hline & MIC & MBC & MIC & $\mathrm{MBC}$ & MIC & MBC & MIC & MBC \\
\hline $0.5 \mu \mathrm{g} / \mathrm{ml}$ & + & + & + & + & + & + & + & + \\
\hline $2.5 \mu \mathrm{g} / \mathrm{ml}$ & + & + & + & + & + & + & + & + \\
\hline $5.0 \mu \mathrm{g} / \mathrm{ml}$ & + & + & + & + & + & + & + & + \\
\hline $10.0 \mu \mathrm{g} / \mathrm{ml}$ & + & + & - & + & + & + & + & + \\
\hline $25.0 \mu \mathrm{g} / \mathrm{ml}$ & - & + & - & - & - & + & - & + \\
\hline $50.0 \mu \mathrm{g} / \mathrm{ml}$ & - & - & - & - & - & - & - & - \\
\hline $75.0 \mu \mathrm{g} / \mathrm{ml}$ & - & - & - & - & - & - & - & - \\
\hline $100.0 \mu \mathrm{g} / \mathrm{ml}$ & - & - & - & - & - & - & - & - \\
\hline $200.0 \mu \mathrm{g} / \mathrm{ml}$ & - & - & - & - & - & - & - & - \\
\hline $500.0 \mu \mathrm{g} / \mathrm{ml}$ & - & - & - & - & - & - & - & - \\
\hline Key: & \multicolumn{8}{|c|}{$\begin{array}{l}\text { (+) Indicates growth } \\
(-) \text { Indicates no growth }\end{array}$} \\
\hline
\end{tabular}




\section{Cytotoxicity assay}

We observed that Ruta AgNPs suppressed growth of cancer cells and percentage cell viability were $48.5 \%$ in 200 $\mu \mathrm{g} / \mathrm{ml}$ and $22.5 \%$ in $400 \mu \mathrm{g} / \mathrm{ml}$ (Fig.7). The results indicated that with the increase in Ruta AgNPs concentration there was a significant $(p<0.05)$ decrease in cell viability of HepG2 as compared to control.

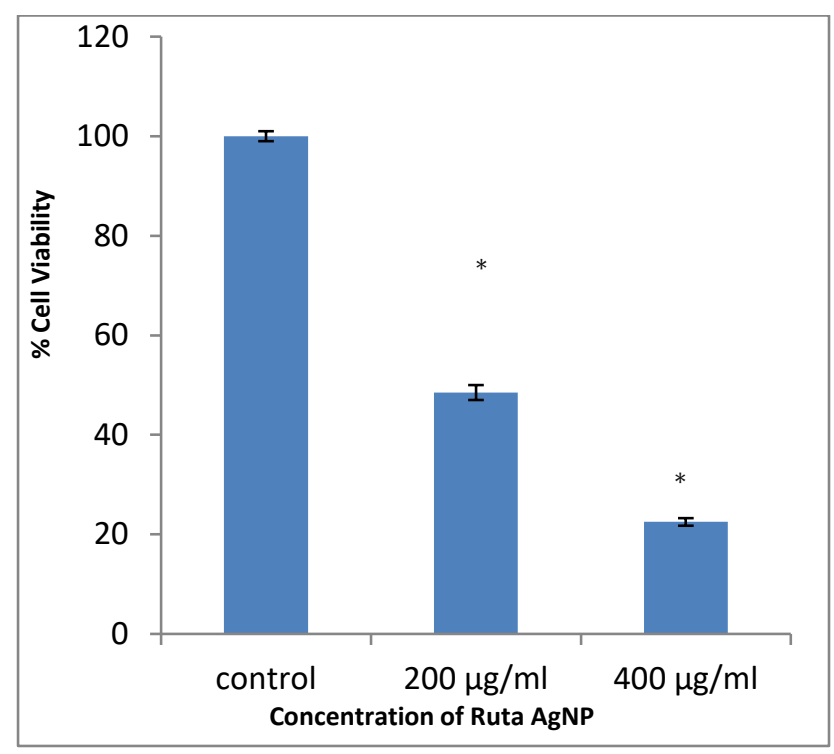

Figure 7: Cytotoxicity effect of Ruta AgNPs on viability of Hep-G2 cell lines. Each value is expressed as a mean \pm SD $(n=6) . P<0.05$ was considered statistically significant compared to control.

\section{ABTS Free Radical Scavenging Assay}

The biologically synthesized Ruta AgNP showed good radical scavenging activity (Fig. 8) as the well-known antioxidant ascorbic acid. With the increase in the concentration of AgNP's ability to scavenge free radicals also increased on reaction with ABTS radicals.

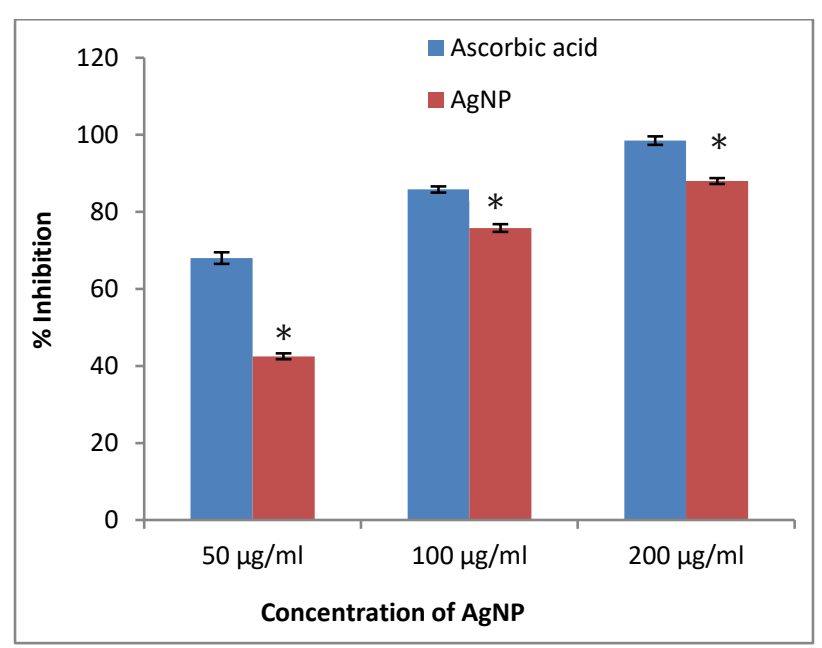

Figure 8. ABTS $\bullet+$ radical-scavenging assay of Ruta AgNP. Ascorbic acid was used as the positive control. Each value is expressed as a mean $\pm S D(n=6) . P<0.05$ was considered statistically significant compared to control.

\section{DISCUSSION}

We observed formation of the AgNPs during the plant extract mediated reduction process, indicated by change in the color of the reaction solution from colorless to dark brown. The property of silver nanoparticles to exhibit surface Plasmon resonance (SPR) and related optical properties was utilized for analyzing the UV-Visible spectrum of synthesized nanoparticle ${ }^{8}$. The absorption peak in the range of $420-450 \mathrm{~nm}$ confirmed the formation of Ruta graveolens $L$. mediated silver nanoparticle formation. Due to the property of SPR the absorption of visible radiations imparts various colors to nanoparticles. The TEM micrograph \& the particle size distribution suggest that the size of the nanoparticles was around 15 $\mathrm{nm}$ and they were of spherical shape \& monodispersed.

The zeta potential of the biosynthesized AgNPs was found as a sharp peak at $-35 \mathrm{mV}$. The observed zeta potential value in the current study shows that silver nanoparticles synthesized is negatively charged and dispersed in the medium. Also, the negative value confirms the particles repulsion and demonstrates their stability, with higher magnitude potentials exhibiting increased electrostatic repulsion and therefore increased stability. It is generally argued that particles with zeta potentials greater than +30 $\mathrm{mV}$ and less than $-30 \mathrm{mV}$ are considered stable for colloidal dispersions in the absence of steric stabilization ${ }^{9,10}$. DLS analysis found around $130 \mathrm{~nm}$ is based on the diffusive motion of particles in solution (Brownian motion). The hydrodynamic diameter measurement provides information on the aggregation state of nanoparticle solutions. In the current investigation, DLS for the synthesized nanoparticle is slightly higher than their TEM size which shows that our nanoparticle preparation is a stable unaggregated colloidal solution.

Results obtained for FTIR measurements were confirmatory to identify major functional groups in the Ruta extract and their possible involvement in the synthesis and stabilization of silver nanoparticles. The spectrum obtained, with peaks at 3507, 2829, 1579, 1020, 755 are characteristic of flavonoids and terpenoids present in the stem. FTIR results suggest that Ruta graveolens acts as a good bioreductant for biosynthesis of silver nanoparticles.

Antibacterial effect of Ruta silver nanoparticles was observed in tested microorganisms. One of the proposed mechanisms for antimicrobial activity of AgNPs reported ${ }^{11}$ is that silver ions led to transformation of the bacterial DNA from the natural relaxed state to a condensed state in which the DNA molecule loses its replication ability. There are reports suggesting the action of AgNPs will damage the cell membrane, interrupt the metabolic activity, and subsequently lead to denaturation of protein and finally cell death $12,13,14$. Also AgNPs could also produce several reactive oxygen species (ROS) which are toxic to the bacteria ${ }^{15}$. Reactive oxygen species are responsible for oxidation of cellular components i.e. cellular DNA and protein. Upon oxidation of these components, cell 
becomes unstable at physiological and genetic level causing failure of metabolism and cell division process.

Free radical scavenging activity of Ruta AgNPs was proved by ABTS assay. The presence of important phytoconstituents such as flavanoids and terpenoids observed in FTIR spectrum also substantiates the ability of Ruta AgNPs to show antioxidant activity. The antioxidant potential can be attributed to the specific functional groups of phytoconstituents present in Ruta plant extract that are actually involved in the capping and stabilization of biologically synthesized silver nanoparticles. Given that this study is the first investigation on the cytotoxicity of Ruta stem AgNPs, an exact mechanism for its anticancer properties remains to be unclear and needs further evaluation. Free radical scavenging activity of the Ruta mediated silver nanoparticles can be correlated with cytotoxicity action in cancer cells. Several studies ${ }^{16,17}$ have shown that polyphenols and flavanoids are toxic to cancerous cells while being harmless to healthy cells.

\section{CONCLUSION}

The biological method of synthesis of silver nanoparticles can conveniently overcome the complications of biosafety of the chemicals used for the generation of nanoparticles. Recent reports show that phytonanotechnology is gaining great importance with more than 20 nanoparticle therapeutics available. This study adds another feature to the medicinal plant Ruta graveolens, for its ability to successfully formulate AgNPs, which could be used effectively for their antibacterial and antiproliferative properties.

Acknowledgement: The first author gratefully acknowledges University of Mumbai for funding in the category of Minor Research Project for faculty (MRP No.74, 2017-18). Authors are thankful to Indian Institute of Technology, Mumbai for SEM, FTIR measurements.

\section{REFERENCES}

1. Sharma VK, Yngard RA, Lin Y. Silver nanoparticles: green synthesis and their antimicrobial activities. Adv Colloid Interface Sci. 2009; 145(1-2): 83-96. http://dx.doi.org/10.1016/j.cis.2008.09.002

2. Aromal A, Philip D. Green synthesis of gold nanoparticles using Trigonella foenum-graecum and its size-dependent catalytic activity.

3. Ratheesh M, Shyni GL, Helen A. Methanolic extract of Ruta graveolens L. inhibits inflammation and oxidative stress in adjuvant induced model of arthritis in rats. Inflammopharmacology. 2009; 17(2): 100-5. http://dx.doi.org/10.1007/s10787-009-8044-0

4. Kuzovkina I, Al'terman I, Schneider B. Specific accumulation and revised structures of acridone alkaloid glucosides in the tips of transformed roots of Ruta graveolens. Phytochemistry.2004; 65(8): 1095-100. http://dx.doi.org/10.1016/j.phytochem.2004.03.003
5. Garibo D, Borbón-Nuñez HA, de León JN, Mendoza EG, Estrada I, Toledano-Magaña $Y$, Tiznado $H$, Ovalle-Marroquin M, Soto-Ramos AG, Blanco A, Rodríguez JA. Green synthesis of silver nanoparticles using Lysiloma acapulcensis exhibit high-antimicrobial activity. Scientific reports. 2020 Jul 30; 10(1): 1-1.

6. Mosmann T. Rapid colorimetric assay for cellular growth and survival: application to proliferation and cytotoxicity assays. J Immunol Methods. 1983; 65(1-2): 55-63. http://dx.doi.org/10.1016/00221759(83)90303-4

7. Fotakis $\mathrm{G}$, Timbrell JA. In vitro cytotoxicity assays: comparison of LDH, neutral red, MTT and protein assay in hepatoma cell lines following exposure to cadmium chloride. Toxicol Lett. 2006; 160(2): 171-7. http://dx.doi.org/10.1016/j.toxlet.2005.07.001

8. Re R, Pellegrini N, Proteggente A, Pannala A, Yang M, Rice-Evans C. Antioxidant activity applying an improved $A B T S$ radical cation decolorization assay. Free Radic Biol Med. 1999; 26(9-10): 1231-7. http://dx.doi.org/10.1016/s0891-5849(98)00315-3

9. Ibrahim HMM. Green synthesis and characterization of silver nanoparticles using banana peel extract and their antimicrobial activity against representative microorganisms. J Radiat Res Appl Sci. 2015; 8(3): 265-75. http://dx.doi.org/10.1016/j.jrras.2015.01.007

10. Bootz A, Vogel V, Schubert D, Kreuter J. Comparison of scanning electron microscopy, dynamic light scattering and analytical ultracentrifugation for the sizing of poly (butyl cyanoacrylate) nanoparticles. Eur J Pharm Biopharm. 2004; 57(2): 369-75. http://dx.doi.org/10.1016/s0939-6411(03)00193-0

11. Nayak D, Ashe S, Rauta PR, Kumari M, Nayak B. Bark extract mediated green synthesis of silver nanoparticles: Evaluation of antimicrobial activity and antiproliferative response against osteosarcoma. Mater Sci Eng C Mater Biol Appl. 2016; 58: 44-52. http://dx.doi.org/10.1016/j.msec.2015.08.022

12. Zhang X-F, Liu Z-G, Shen W, Gurunathan S. Silver nanoparticles: Synthesis, characterization, properties, applications, and therapeutic approaches. Int J Mol Sci. 2016; 17(9): 1534. http://dx.doi.org/10.3390/ijms17091534

13. Kumar $R$, Münstedt $H$. Silver ion release from antimicrobial polyamide/silver composites. Biomaterials. 2005; 26(14): 2081-8. http://dx.doi.org/10.1016/j.biomaterials.2004.05.030

14. McDonnell G, Russell AD. Antiseptics and disinfectants: activity, action, and resistance. Clin Microbiol Rev .1999; 12(1): 147-79. http://dx.doi.org/10.1128/CMR.12.1.147

15. Pal S, Tak YK, Song JM. Does the antibacterial activity of silver nanoparticles depend on the shape of the nanoparticle? A study of the Gram-negative bacterium Escherichia coli. Appl Environ Microbiol 2007; 73(6): 1712-20. http://dx.doi.org/10.1128/AEM.02218-06

16. Sondi I, Salopek-Sondi B. Silver nanoparticles as antimicrobial agent: a case study on E. coli as a model for Gram-negative bacteria. J Colloid Interface Sci. 2004; 275(1): 177-82. Available from: http://dx.doi.org/10.1016/j.jcis.2004.02.012

17. Carlson C, Hussain SM, Schrand AM, Braydich-Stolle LK, Hess KL, Jones RL, Schlager JJ. Unique cellular interaction of silver nanoparticles: size-dependent generation of reactive oxygen species. J Phys Chem B. 2008; 112(43): 13608-19. http://dx.doi.org/10.1021/jp712087m

Source of Support: The author(s) received no financial support for the research, authorship, and/or publication of this article.

Conflict of Interest: The author(s) declared no potential conflicts of interest with respect to the research, authorship, and/or publication of this article.

For any question relates to this article, please reach us at: globalresearchonline@rediffmail.com

New manuscripts for publication can be submitted at: submit@globalresearchonline.net and submit_ijpsrr@rediffmail.com 